\title{
Hybridity in Graham Greene's The Quiet American and The Comedians
}

\section{Golshid Pourviseh}

\author{
University of Isfahan \\ Email: gpourviseh@gmail.com
}

\section{Hossein Pirnajmuddin}

Assistant Professor of English Literature at University of Isfahan, Iran

Doi:10.5901/mjss.2014.v5n7p609

\begin{abstract}
Most of Graham Greene's novels are ample fields for examining notions in postcolonial studies. In this essay the notion of hybridity, focal in colonial and poscolonial studies, is probed in two of Greene's novels, The Quiet American (1955) and The Comedians (1966). These two novels, it is argued, are centrally concerned with the theme of identity in the context of colonialism and imperialism. The characters in these novels are essentially diasporic and their sense of identity could be best described as 'hybrid.'
\end{abstract}

Keywords: Graham Greene, The Quiet American, The Comedians, colonialism, postcolonialism, hybridity, diaspora.

\section{Introduction}

Hybridity of cultures and identity is a central issue in the work of postcolonial theorists, especially Homi Bhabha who argues that the construction of the subject is a process through which the two sides of the interaction, in this case the colonizer and the colonized, construct each other's identity in a mutual relation. Graham Greene is concerned with this issue in many of his two novels, particularly in The Quiet American and The Comedians. He adroitly juxtaposes different characters with different nationalities and different cultures; He brings them together and makes them interact with each other in what Bahabha has called "Third Space" (qtd. in Rivkin and Ryan 2385). These characters arguably form a hybrid community belonging neither to the colonizers' or the colonized cultures.

As stated by Edward Said, the matter of 'crossing the borders' is one of significant issues in the postcolonial studies. Said believes that imperialism intensifies "the mixture of cultures and identities on a global scale" (Culture 407). The world presnted in The Comedians and The Quiet American is one in which various cultures clash. The characters inhabiting this fictional world are stripped of a sense of the past and history and feel that they are rootless; they are from nowhere or everywhere.

In what follows the issue of hybridity of culture and identity, in conjuction with the related notions of diaspora and migration, central in postcolonial studies, in the above-mentioed novels by Graham Greene.

\section{Postcolonial Studies}

One of the main issues discussed in postcolonial studies is the notion of 'hybridity' to which Said also refers in Culture and Imperialism (1993). As he points out, "partly because of empire, all cultures are involved in one another; none is single and pure, all are hybrid, heterogeneous, extraordinary differentiated, and unmonolithic" (xxix). In this sense, hybridity refers to the situation in which the colonized and the colonizer's cultures interact with each other in a new third space. This hybridity is also the feature of the literature produced by the colonized people in such a situation.

Attributing an indeterminate status to nationalities, ethnicities, and identities, Bhabha characterizes them as hybrid. In defining hybridity, he focuses on the interdependence of the colonizer and the colonized in "the mutual construction of their subjectivities" (Bertens 118). In "Commitment to Theory" (1994), Bhabha defines 'hybridity' as what "is new, neither the one nor the other," but something else which is produced in a space which he calls the "Third Space of enunciation" (atd. in Rivkin and Ryan 2385). This is the space which he regards as the precondition for the articulation of cultural difference (2397). If as Bhabha says, "all cultural statements and systems are constructed in this contradictory and 
ambivalent space of enunciation," then there is no claim to the purity of cultures (2396). It is this in-between space that leads to the idea of an international culture based on the articulation of the hybridity, not the diversity of cultures (2397). While the notion of diversity separates cultures from each other, the notion of hybridity mingles them and this is against the will of the center.

As Ashcroft et al. notice, Bhabha's notion of the hybrid nature of postcolonial culture, as a different model of resistance, challenges the claims of the imperialist culture to authenticity and superiority. It disrupts the imperial binary systems for an emphasis on the "dialectical effects of the colonial encounter" (Post-colonial Studies 121). Just as the postcolonial identity is formed in an ambivalent space of colonial encounter, the imperial relation to its periphery cannot be just one-directional from the colonizer to the colonized. Rather the relation is cross-cultural; that is, to know itself, the imperial metropolis has to be in a 'mutual' relation with the periphery (27). Ashcroft et al. believe that in today's postcolonial world, "destructive cultural encounter" has given its place to "an acceptance of difference on equal terms" (35). Many literary theorists nowadays focus on the idea of 'cross-culturality' as the only potential solution to put an end to the long history of "human conquest and annihilation justified by the myth of group 'purity"' (Ibid, 35).

Another major feature of postcolonial studies is the concern with place and displacement. There is a very essential connection between 'self' and 'place' (Ashcroft et al., The Empire 8). One's definition of self may have been destroyed by dislocation -- which is the result of migration, experience of enslavement, transportation, or voluntary removal -- or by "cultural denigration, the conscious and unconscious oppression of the indigenous personality and culture by a supposedly superior racial or cultural model" (Ibid, 9). However, Bhabha uses the terms 'migrancy', 'dislocation' and 'displacement' metaphorically. He asserts that the havoc resulted from colonialism created a "universal psychic 'migrancy' and a sense of dislocation" (qtd. in Chew and Richards 21).

One of the consequences of global extension of capitalism was the voluntary or forced scattering of increasing numbers of people. Therefore, the concept of diaspora is as "displaced populations attempted to trace a story of unity in the face of dislocation and alienation" (Lazarus 254). For many postcolonial theorists the mobility and fluidity of "diasporan culture' is significant. According to Hall, 'diasporan culture' indicates that identity is not fixed and stable, but something dynamic and changeable. All the things related to identity are exposed to be "reformed and reproduced in conditions of exile and movement" (qtd. in Lazarus 256).

Bill Ashcroft et al. note that, "Colonialism itself was a radically diasporic movement, involving the temporary or permanent dispersion and settlement of millions of Europeans over the entire world" (qtd. in McLeod 69). Since the influence of the imperialism is not only upon the local society, the destruction it causes leads to the change of global culture by the movement of the peoples (The Empire 217-18). Rootless people without histories, wandering in a new world, then, are the byproducts of diaspora and globalization. "The diasporic production of cultural meanings" is one of the main interests of a postcolonial writer, "in which diaspora might disrupt the binary of local and global and problematizes the national, racial and ethnic formulations of identity" (218). As Stuart Hall maintains, the essential matter in a diasporic identity is not 'subjectivity' but 'subject position' (qtd. in Ashcroft et al. 218). Accordingly, the diasporic character in postcolonial writings partakes of fluidity of identity and a constantly changing subject position, both 'geographically' and 'ontologically'. Moreover the diasporic writing, in its 'crossing of borders', opens up the 'horizon of place' (218).

Postcolonial studies also deals with the question of identity. According to Frantz Fanon, colonialism has a very significant effect on the 'realms of the psyche', and if one intends to gain a full understanding of colonization, he should recognize its psychological impact. In his book The Wretched of the Earth (1961) Fanon argues that to be merely free from the empire and colonial domination is not sufficient to eliminate the "colonialists' distorting mirror and to return the subject peoples to their rightful sense of identity" (qtd. in Chew and Richards 12-13).

After Fanon and Said, postcolonial studies considers identities as products of the world in persistent shifting. Although the issues on which identity is grounded, such as race, ethnicity and nationality, appear to be fixed and unchanging, they are always being 'formed and reformed' in a process of constant interaction and change. Accordingly, identities are also in a constant state of shift. Colonialism speeds up the pace of change in that it pushes various cultures into new forms and creates new identities (atd. in Chew and Richards 19). The postcolonial studies concerns with deconstructing "the older language of identity founded upon notions of impermeable entities, such as the nation, culture, and selfhood, and to reconstruct the debate around hybrid and porous formations, such as displacement, dislocation, and migrancy" (lbid).

\section{Hybridity in The Quiet American}

As Edward Said notes in Culture and Imperialism, colonialism leads cultures to be involved in one another, therefore, 
there is no single and pure culture and all of them are hybrid and heterogeneous (xxix). In such a situation the cultures of the colonizer and the colonized interact with each other in a new third space. Bergonzi believes that the relationship between Phuong, the Vietnamese girl, and Fowler, the English journalist and the narrator of the novel, is an uncertain union of two totally different worlds, mainly because they speak in French, the language of the imperial power which belongs to none of them (147). However, going through the novel, there seems to be no real separation between the two. They accept their cultural differences and found their relationship on such distinctions. That is why after a period of separation, when Phuong leaves Fowler for Pyle, she returns to Fowler so they can stay together and marry:

"Do you have to go?"

"No," I said, "I don't have to go... Here's your happy ending."

"But it is wonderful. I must go and tell my sister. She'll be so pleased. I will say to her, "Do you know who I am? I am the second Mrs. Fowlair.'" (QA 185)

As Bhabha theorizes, the concept of hybridity questions the limited views about cultural identity and aims at the creation of a kind of community where different groups with different cultures while accepting their differences, form a union of "coalition" (qtd. in Leitch 2378). The relations between Fowler and Phuong, Pyle and Phuong, Fowler and Dominguez and many others in the novel seem to form such a union.

Bhabha also believes that the hybrid nature of postcolonial identity is a kind of resistance and opposition to the claim that imperialist culture is superior and authentic (qtd. in Ashcroft et al., P S 121). The relation of the imperialist and the marginal is cross-cultural; that is, for the imperial metropolis to know itself, there has to be a 'mutual' relation with the periphery (Ibid, 27). Dominguez is an Indian who works with Thomas Fowler in Vietnam and gives him information. It is through such a relationship that Fowler, as a European, knows more about his own identity and also his differences with Dominguez. Fowler cherishes his characteristics, especially his "absolute love of truth". It is also likely that by praising him, Fowler intends to contrast him with Pyle, who is blinded to the truth and reality,

I was fond of Dominguez: where other men carry their pride like a skin-disease on the surface, sensitive to the least touch, his pride was deeply hidden and reduced to the smallest proportion possible, I think, for any human being. All that you encountered in daily contact with him was gentleness and humility and absolute love of truth... Perhaps truth and humility go together; so many lies come from our pride, in my profession a reporter's pride, the desire to file a better story than the other man's, and it was Dominguez who helped me not to care, to withstand all those telegrams from home asking why I had not covered so and so's story or the report of someone else which I knew to be untrue. (QA 139)

It can be said that the relationship between Fowler and Dominguez or between Fowler and Phuong instances 'transculturation' since it is a mutual one between the periphery and the center, in which, as Marry Louise Pratt believes, different cultures encounter, conflict, and consequently construct each other's identity through their relations (qtd. in Ashcroft et al., PS 233).

There is a very close relation between identity and place. One's identity may have been disrupted by dislocation or cultural denigration (Ashcroft et al. The Empire 8-9). In The Quiet American displacement figures prominently. Almost all of the main characters suffer from a kind of homelessness. Characters such as Fowler, who is forced to migrate to Vietnam to cover the war news, or Pyle, who migrates voluntarily to this country to set up a Third Force, and Phuong, a 'psychological refugee' - to use Bhabha's words - who, tired of war and the crisis in Vietnam, dreams about migration to England or America, are all victims of colonialism.

As Lazarus contends, there is a close relation between the lack of hope in anticolonial nationalism and migration when people from the underprivileged nations attempt to find a place and living in the "centers of economic control" (247). In fact, migrants abandons the 'old foundations' and 'previous grounded ways of thinking about identity' in the cosmopolitan positions (249). Phuong is in such a situation. She wants to leave Vietnam and go with either Fowler or Pyle to live in England or America at any cost. She imagines herself in different places in America and London in her dreams, although she has a little knowledge of those places.

"I could come with you. I would like to see London," Phuong said.

"It would be very uncomfortable for you if we were not married."

"But perhaps your wife will divorce you."

"Perhaps."

"I will come with you anyway," she said. She meant it, but I could see in her eyes the long train of thought begins..

She said, "Are there skyscrapers in London?"...

"No," I said, "you have to go to America for them." She gave me a quick look over the needle and registered her 
mistake. Then as she kneaded the opium she began to talk at random of what clothes she would wear in London, where we should live, of the Tube-trains she had read about in a novel, and the double-decker buses: would we fly or go by sea? "And the Statue of Liberty..." she said. "No, Phuong, that's American too." (QA 75)

As one notices, Phuong is willing to abandon her previous ways of living, clothing and behaving in new places, where she hopes to go to, where, in fact, she is susceptible to gain a new identity.

Bhabha postulates that the colonized people are exposed to two different and somewhat distinct views of the world: that of the colonizer and that of himself or herself which is conquered by the colonizer. He also acknowledges that to none of these two cultures the colonized belong since "neither culture feels like home" (qtd. in Bressler 241). Bhabha calls such feeling of homelessness and being caught between two clashing cultures, "unhomeliness", which leads the colonial subject to become a "psychological refugee" (Ibid, 241). Phuong, her sister, and other Vietnamese characters in the novel experience such unhomeliness in their own country. The language and culture of the colonizers are imposed on them. They belong to neither their own culture nor the colonizers'.

Pyle is another homeless character who has lost his identity through diasporic movement and coming to Vietnam. After Pyle's death Fowler is asked to identify his body in a police mortuary, where he seems "more than ever out of place" (QA 10). He thinks that Pyle should have stayed at home, and identifies him with the culture that produced him. The reality is that here in Vietnam Pyle has no stable sense of identity:

I saw him in a family snapshot album, riding on a dude ranch, bathing on Long Island, photographed with his colleagues in some apartment on the twenty-third floor. He belonged to the skyscraper and the express lift, the ice-cream and the dry Martinis, milk at lunch, and chicken sandwich on the Merchant Limited. (QA 10)

Fowler is one of the displaced people who attempt to follow the "story of unity in the face of dislocation and alienation" (Lazarus 254). As Stuart Hall puts it, identity is not something fixed and solid but it is exposed to be changed and even reconstructed in conditions of exile and movement (qtd in Lazarus 256). Fowler's identity is subject to change in the new nation, Vietnam. He becomes separated from his previous culture and does not like to return to his own country. For him, the idea of 'home' is dissociated from England or anything related to it. When he is ordered to return to England to be a foreign editor, he gets depressed and sees no life for himself there. He goes to Pietri, a French officer, "another man who had no particular desire to go home" in Fowler's description, to talk to him, thinking that "it seemed impossible" that he "could ever have a life again," away from all the places and things in Vietnam: "I said, 'I'm going back.' 'Home?' Pietri asked. 'No. England' (QA 63).

It seems that for Fowler the concept of home has been changed. He does not consider England as his home, so he tries to convince the Managing Editor to remain in Vietnam:

I wrote: "For private reasons I am very unhappy at being moved from Vietnam. I don't think I can do my best work in England, where there will be not only financial but family strains. Indeed, if I could afford it I would resign rather than return to the U. K. I only mention this as showing the strength of my objection (QA 64).

\section{Hybridity in The Comedians}

Bhabha's notion of 'cultural difference' is well applicable to a novel like The Comedians in which characters are from different countries and nations, coming together to let their mutual relations with each other construct their present identities. 'Cultural difference', which focuses on the existence of a "Third Space' within cultural relations, rejects the idea of cultural purity, which is the focus of Western imperial thought. In a hybrid world like today's, accepting others' differences is the only way to attain stable peace.

Hybridity is the offspring of colonialism. In defining hybridity Bhabha focuses on the interdependence of the colonizer and the colonized who construct their 'subjectivities' in a mutual relationship (Bertens 118). In The Comedians Jones divides "the world into two parts - the toffs and the tarts" (Comedians 21). And he believes that toffs have "reason, intelligence, character" and independent identities from the tarts who "can't do without the toffs," who "pick a living here and there" (Comedians 21). Here Jones refers to the interdependency of the identities but he misses the point that without 'tarts', 'toffs' cannot have any sense of identity.

Bhabha believes that when two cultures clash and intermingle, the characteristics of the newly created culture changes each of the two cultures. This dynamic and interactive process, which is called hybridity, challenges the claims of the imperialist culture to authenticity and superiority (Ashcroft et al. 121); that is, to know itself, the colonizer has to be 
in a mutual relation with the colonized. One can notice such a relation between both Jones and Brown and the Haitian people.

The Comedians can be considered as depicting a world in which characters with different nationalities are juxtaposed in a way that, regardless of their histories and traditions, they interact with each other and reconstruct their identities. The major characters such as Brown, the narrator of the story, and Jones are actually from nowhere and with no identity. They have brought with them no history and no past. This could be the result of "globalization." As Tong et al. point out, the consequence of globalization is its persistent attempt to "flatten" the world, to obliterate "traditional boundaries and differences within the international order of nation-states and erase the memories and histories of those boundaries and differences by isolating our thinking and experience in a disconnected moment of the present" (2). Therefore, in a "flat" world, "the end of history and the beginning of non-history" is taken for granted (2). In such a flat world there is no difference between the people; it is not important where they come from or what identity or culture they have. And Brown points this out in his narrative, mentioning the names Brown, Jones, and Smith which are very common names, "Again I was aware of the three names, interchangeable like comic masks in a farce" (Comedians 18).

During his narrative Brown always struggles to find an identity or a past for himself. However, each time he fails as he casts doubt on what he has constructed as his identity with words such as "perhaps", "uncertain" and "doubtful",

From time to time in my life I had found it necessary to provide a curriculum vitae. It usually began something like this. Born 1906 at Monte Carlo of British parents. Educated at the Jesuit College of the Visitation. Many prizes for Latin verses and Latin prose composition. Embarked early on a business career ... Of course I varied the details of that career according to the recipient of the curriculum. What a lot too was left out or was of doubtful truth in even those opening statements. My mother was certainly not British, and to this day I am uncertain whether she was French perhaps she was a rare Monegasque. The man she had chosen for my father left Monte Carlo before my birth. Perhaps his name was Brown. There is a ring of truth in the name Brown - she wasn't usually so modest in her choice. (Comedians 59)

Fanon asserts that, as a result of colonialism, both the colonized -considered as the "other," any person defined as "different from" - and the colonizer suffer from "psychic warping," which causes "a collapse of the ego" (qtd. in Bressler 239). Moreover, Bhabha believes that in the colonial world the existence of a fixed and stable identity is impossible, since the colonizer's identity does not have origin in itself and has to be constructed through interaction with the colonized (qtd in Bertens 207). Brown has forgotten all about his past: "I find it strange to think now of my Latin verses and compositions - all that knowledge has vanished as completely as my father" (Comedians 59). He has no particular identity or origin, and has no interest to know about it:

\footnotetext{
... And my real father? He had deposited not so much as one childish memory. Presumably he was dead, but I wasn't sure ... I felt no genuine curiosity about him; nor had I any wish to seek him out or find his tombstone, which was possibly, but not certainly, marked with the name Brown. (Comedians 219)
}

Jones, too, is another character with no clear identity or with many different identities. By his different relations with different people, he tries to construct an identity for himself. He tells a lot of stories about his life, stories whose verity we are never sure of. Globalization facilitates contacts between people and different peoples of different cultures. Consequently, such relations destroy the colonizer's confidence in having a monolithic and unified identity. Both Brown and Jones are apparently from England, the country of the colonizers, but in their relations with other people of various cultures seem to erode their identities as such.

As already mentioned, there is a very close relation between one's identity and 'place' in a way that the definition of self can be destroyed by dislocation (Ashcroft et al., Empire 8-9). The concept of dislocation or, as Bhabha calls it, unhomeliness, refers not only to those who have moved - by force or voluntarily - from their countries and homeland but to those who have been colonized by the colonizers. For, when the two cultures, that of the colonizer and the colonized, clash, the colonized people feel that they do not belong to any of them because "neither culture feels like home" (qtd. in Bressler 241). Bhabha also contends that the destruction which is the result of colonialism has created a "universal psychic migrancy and a sense of dislocation" (qtd. in Chew and Ricards 21).

Almost all of the characters in the novel suffer from homelessness. The narrator of the story always seeks a home. He knows that here in Haiti he has no place: "The fire-flies moved among the trees and lit intermittently a world in which we had no part. We, the uncoloured, were all of us too far away from home" (Comedians 159). "[l] should never have come to this country" (Comedians 180), he says, because he is a "stranger" (Comedians 180), however, he knows that he, like Jones, does not have "anywhere else to go" (Comedians 15) and that he comes from nowhere: "I was born in 
Monaco. That is almost the same as being a citizen of nowhere" (Comedians 231). Jones and Brown are diasporic characters who are trying to "trace a story of unity in the face of dislocation and alienation", to use Lazarus' words (254).

As Stuart Hall observes, the diasporic identity is dependent on the 'subject position' rather than its 'subjectivity'. Hence, the diasporic character in postcolonial writings has fluidity in identity and a constantly changing subject position, 'geographically' and 'ontologically' (qtd. in Ashcroft et al., The Empire 218). Brown acknowledges the reality that it is dislocation which destroys one's identity; he laments that "No priest had come to represent a father to me, and no region of the earth had taken the place of home" (Comedians 219). He points out to the stone which is put up after Jone's death to honor him, noting that now he seems more homeless than ever:

...I can find no reason to mock the modest stone that commemorates Jones on the far side of the international road which he failed to cross in a country far from home, though I am not to this day absolutely sure of where, geographically speaking, Jones's home lay. (Comedians 1)

\section{Conclusion}

Greene gives a very exact description of the places and people in his fiction and, as Meyers points out, the people he meets suggest his characters (534). Almost all of the characters in the two novels discussed are the victims of colonialism and imperialism; they suffer from a kind of homelessness and consequently disintegration of identity. The sense of identity is disintegrated by dislocation, resulting from migration or voluntary removal, in characters such as Pyle and Fowler (in The Quiet American) or Brown, Jones and Smith (in The Comedians). In the case of the native characters such as Phuong (in The Quiet American) or Marcel (in The Comedians), the disintegration of identity is mostly a result of colonialism, the imposition on the indigenous culture of the paradigms of a supposedly superior culture, that of the West. The Quiet American and The Comedians share the central concern of identity in the context of colonialism and imperialism, an identity which could be best described as 'hybrid.'

\section{References}

Ashcroft, Bill, et al. The Empire Writes Back: Theory and Practice in Post-colonial Literatures. 2nd ed. London: Routledge, 2002. ---. The Post-colonial Studies: The Key Concepts. London: Routledge, 2000.

Bergonzi, Bernard. A Study in Greene: Graham Greene and the Art of the Novel. New York: Oxford University Press, 2006. Bertens, Hans. Literary Theory: The Basics. London: Routledge, 2001.

Bhabha, H. K. "Commitment to Theory." The Location of Culture. Ed. Homi Bhabha. London: Routledge, 1994. Rpt. in The Norton Anthology: Theory and Criticism. Ed. Vincent B. Leitch. New York: Norton \& Company, 2001. 2379-97.

---. "Dissemination: Time, Narrative, and the Margins of the Modern Nation." Nation and Narration. Ed. Homi Bhabha. London: Routledge, 1990, 291-321. Rpt. in Postcolonialism: Critical Concepts. Ed. Diana Brydon. London: Routledge, 2000, Vol. II.

--.. "Signs Taken for Wonders." Literary Theory: An Anthology. $2^{\text {nd }}$ ed. Julie Rivkin and Michael Ryan. USA: Blackwell Publishing Ltd, 2004.

Bressler, Charles E. Literary Criticism: An Introduction to Theory and Practice. $4^{\text {th }}$ ed. New Jersey: Prentice Hall, 2007.

Brydon, Diana. Ed. Postcolonialism: Critical Concepts in Literary and Cultural Studies. London: Routledge, 2000. 5 vols.

Chew, Shirley, and David Richards. Eds. A Concise Companion to Postcolonial Literature. Malden: Wiley-Blackwell, 2010.

Greene, Graham. The Comedians. New York: Penguin, 1966.

---. The Quiet American. New York: Penguin, 1977.

Lazarus, Neil. Ed. The Companion to Postcolonial Literary Studies. London: Cambridge University Press, 2004.

Leitch, Vincent B. Ed. The Norton Anthology: Theory and Criticism. New York: Norton \& Company, 2001.

McLeod, John. Ed. The Routledge Companion to Postcolonial Studies. London: Routledge, 2004.

Meyers, Jeffrey. "Splinter of Ice." The Virginia Quarterly Review 66.3 (Summer 1990): 530-38.

Rivkin, Julie, and Michael Ryan. Eds. Literary Theory: An Anthology. $2^{\text {nd }}$ ed. USA: Blackwell Publishing Ltd, 2004.

Said, Edward. Culture and Imperialism. London: Vintage, 1993.

--.. Orientalism. $2^{\text {nd }}$ ed. London: Penguin, 1995.

Schwarz, Henry, and Sangeeta Ray. Eds. A Companion to Postcolonial Studies. Malden: Blackwell Publishing Ltd., 2005. 